\title{
Sukarno's Thought about Marhaenism
}

\author{
Aminuddin ${ }^{1}, K_{\text {Katimin }}$, Syukri ${ }^{2}$ \\ ${ }^{1}$ Phd Student in state Islamic university of Nort Sumatera (UINSU), Medan, Indonesia \\ ${ }^{2}$ Lecturer in State Islamic University of North Sumatera (UINSU), Medan, Indonesia \\ aminuddin_marpaung@yahoo.com
}

\begin{abstract}
Marhaenism is a pure thought sparked by Soekarno which departs from the most substantial and universal human life needs, namely the Social Conventions of Man, which requires the realization of the welfare of human life that can only be fulfilled if the harmonization between individual independence and social justice has been created. In reality these demands could not be found at the time, and this concern over the problems (the fate of the Indonesian nation) was the starting point of Sukarno's study in giving perspective to the ideology of marhaenism. This group of poor and destitute people is what Soekarno called the Marhaen.
\end{abstract}

Keywords : Marhaenism; ideology; Marxism; Bung Karno

\section{Introduction}

Marhaenism is the ideology of Bung Karno's teachings as a whole, in marhaenism contained a consistent flow of thought, an ideology that defended the people from oppression and extortion of capitalism, colonialism / imperialism and feudalism, in order to build a just and prosperous society, free from all oppression and extortion, both by the nation and the people of mankind.

For Soekarno, the ideology of marhaenism was the ideology of struggle for groups of people who were impoverished by a system of colonialism, imperialism, feudalism and capitalism. To be able to understand marhaenism according to Soekarno, he must master two knowledge. First, Knowledge of the situation and conditions of Indonesia, and Second, Knowledge of Marxism. Soekarno repeatedly asserted that anyone could not understand marhaenism if they did not understand Marxism first. Based on this, it can be concluded that there is also a strong reason that marhaenism is Marxism that is adapted to the conditions in Indonesian society itself.

When Soekarno looked at Marxism, he found that Marxism consisted of two things that had to be distinguished; philosophy of materialism and historical materialism. According to him the atheist materialism philosophy is not in accordance with Indonesian life. Historicalmaterialism can be used as a thinking method for analyzing social life in Indonesia. Historicalmaterialism is not a teaching or ideology but solely is a social theory that can be used to analyze social conditions. By using historical-materialism as a knife of analysis, Bung Karno discovered that the Indonesian people, most of whom were small farmers, lived because they were oppressed by a system that confined them, namely foreign nation's colonialism / imperialism which was a child of capitalism and Indonesian feudalism. As a result of the oppression and extortion of the system, the Indonesian people are unable to realize the demands of their conscience. Departing from that idea to defend the oppressed people, Bung Karno gave birth to the ideology of marhaenism.

\section{Review of Literatures}

The term ideology comes from the word Idea which means ideas, concepts, basic understanding; and logos which means science. The word Idea comes from the eidos Greek 
word which means form. Besides that there is the word idein which means to see. So literally, ideology means the knowledge of basic notions. In the everyday sense, the word idea is equated with the ideals. The ideals in question are fixed ideals that must be achieved so that the fixed ideals are at the same time a basis, a view or an understanding. ${ }^{1}$

Attention to the concept of ideology developed because of the influence of Karl Marx. Ideology becomes an important vocabulary in political and economic thought. Karl Marx interpreted ideology as a view of life developed based on the interests of certain groups or social classes in the political or socio-economic fields. In this sense, ideology is part of what he calls Uberbau or the superstructure that is founded on forces which have the factors of production which determine its style, and therefore the truth is relative and is only true for certain groups. ${ }^{2}$ Thus, ideology is a relative idea because it reflects the strength of the layer.

While still in school at HBS, Soekarno read everything he could. Perhaps when he in Bandung, he could sort out the knowledge he had gained from his reading in Surabaya. The person who helped him in this matter was D.M.G. Koch. Marcel Koch who was born in 1881 grew up in a Marxist family. But it gradually shifted to adopting a democratic socialism and becoming a member of the ISDP. In 1925 Koch got a job as manager of the Department of State Companies library. After getting acquainted with Koch, Soekarno often visited him at his home on the Papandayan road not far from Regentsweg. ${ }^{3}$

Sukarno's Marxist view was based on Kautsky's Marxist ideology. Karl Kautsky is recognized internationally as an interpreter of Marxist ideology. Such recognition was given to Kautsky, who in his youth in London met personally with Marx and Engels, because he had written a large number of books and articles explaining Marx's teachings thoroughly and easily understood. At first Kautsky was a revolutionary Marxist, but later on by sticking to the teachings of Marx and Engels, he became an evolutionary socialist. Then by Soekarno the ideology of evolutionary Marxism from Kautsky was changed to a concept of its own for Indonesian nationalism.

The theory of Marxism was carried out by Karl Marx and Engels for a long time throughout the 19th century period. During that time, there were stages which showed different emphases, even contradictions in their thinking. In 1945, when he was 27 years old, Marx was greatly influenced by the three main schools of thought that influenced his theories. When that school of thought was German Philosophy (Hegel), French Utopia Socialism, and British Classical Economic theory. ${ }^{4}$

Just as in the way of Kautsky's thinking, the proletariat ${ }^{5}$ will gain power when elections are held, so will the Indonesian people at one time get independence because of the number of natives who have their numerical advantages. In other words, a peaceful revolution will definitely take place. The ultimate goal might be interpreted as revolutionary, but the effort to get it is definitely not revolutionary. In addition to the name Kautsky, Soekarno also found the name Bakoenin. He did not approve of the Marxist assumption that only the industrial

\footnotetext{
${ }^{1}$ Kaelan, et.al, Pendidikan Kewarganegaraan (Yogyakarta: Paradigma, 2007), p. 152.

${ }^{2}$ Ibid.,

${ }^{3}$ Lambert Giebels, Soekarno: Biografi 1901-1950 (Jakarta: Grasindo, 2001) p. 58

${ }^{4}$ Hartisekar,et.al, Mewaspadai Kuda Troya Komunisme di Era Reformasi (Jakarta: Pustaka Sarana Kajian, 2001), p. 24.

${ }^{5}$ Proletariat is a class that seeks life from the sale of its own energy or in other words Proletariat is a person who sells energy to other people, by not participating in owning the means of production. Proletariat is a laborer, with no means of production. But our nation consists of tens of millions of people, not all of which are included in this Proletarian term. Ibid., p. 29
} 
proletariat of urban areas could be used as a fighting force in a revolutionary struggle. Bakoenin also argues that there is no denying that small farmers are allies that are absolutely necessary in this struggle.

Then by Soekarno, the ideas of the two figures above were put together. Kautsky and Bakoenin's ideas by Sukarno were combined into an ideology which he called Marhaenism. ${ }^{6}$ This theory he developed while cycling around Bandung, he met a farmer who was working in the rice fields. Soekarno conversed with him and when he asked:

"Who owns this field that is being worked on by the farmer, the farmer answers that it is his own land, as well as the hoe he uses, the rice he harvests later, and the simple hut on the edge of the rice field. He did not hire anyone, said the farmer, and he did not work for anyone. Soekarno realized that this small farmer, although very poor, could be considered as an independent businessman and that this also applies to the satay seller, the fisherman, the person who carried the goods with his dock, and many more. He asked the name of the farmer. "Marhaen", he answered. Thus, at that time the name was born for a theory which always inspired Soekarno's political ideology which he would convincingly submit:

"Our tens of poor workers don't work for others and other people don't work for them. Not that one human being is sucked by another human being. Marhaenism is Indonesian socialism in practice". 7

In the Speeches of Marhaen and the Proletariat delivered by Sukarno in front of a PNI meeting on 3 July 1957, precisely on the thirty birthday of the party, Soekarno said:

"For example, brothers and sisters, the wheelman (Bandung term) is not a laborer, not a farmer, what class is he? Fishermen on the beach, not laborers, not farmers, what group is it? The small traders, who hold stalls, not laborers, not farmers, are they groups? Ladies and Gentlemen, there was one famous term in 1926, among the people of Indonesia, namely Proletarian words. This Proletarian word is often not understood by its meaning. This Proletarian word was used in 1926 to describe all the people who were giddy, the Proletariat. But he is not a proletarian at all. I have explained to you, old friends, because I used Marhaen's words, none other than because I was one day walking in the fields of Kiduleun Cigereleng, brothers I met people who were taking a break there, I asked him: "Brother, who does this land have?" So, he also owns the production equipment, he owns this rice field. This is hoe, who has it? Servant servant. Who do you have these tools? Servant servant. But brother, you live in poverty. Yes, I live poorly. At that time, brothers and sisters, I asked him: "Who is your name?" "Heh, servant Marhaen". At that time he said that he had a name, Marhaen. Received inspiration at that time, brothers and sisters, Bung Karno. La, this name will hold on to me. I will use this name to describe the giddy Indonesian people. ${ }^{8}$

This word has dominated political debate in Indonesia since around 1932. Previously, the word was virtually unknown at all. Political circles for the first time heard the word in Sukarno's defense speech. He explained that the Indonesian people, as a result of centuries of imperialist domination, were typical of small people: "He was an association of life which was largely composed of small peasants, small workers, small traders, small sailors, short said ... the chromo and the marines are all small." 9

\footnotetext{
${ }^{6}$ Giebels, Soekarno, p. 59

${ }^{7}$ Ibid.,

${ }^{8}$ Herbert Feith, et.al, The Indonesian Political Thingking, 1945-1965. p. 142

${ }^{9}$ Bernhard Dham, Soekarno dan Perjuangan Kemerdekaan (Jakarta: LP3ES, 1987) p. 187.
} 
Soekarno had a very good opportunity to give this picture in the court session. He not only described their condition, but also explained to the Panel of Judges how the National Party must be guided by those who are the people:

(In) this social life that is almost full of Kromo and Marhaen people, we are from the Indonesian National Party ..., we also have to run a Chromoistic and Marhaenistic politics too ... It is not possible to try to defeat imperialism by pushing it out with the power of economic competition, not It was we who tried to weaken their power with self-contained power which was nationally economical as in India. We can only defeat him with the actions of Kang Kromo and Kang Marhaen with the maximum mass of ethnic actions. We try to compile the millions of masses of energy, try to divert the energy of all Indonesian intellectuals towards the mass order ... "In the masses, with the masses, for the masses!", That is what must be our watchword and the motto of each Indonesian people who want to fight for the safety of the homeland and the nation!

A variety of small people need to be united, but the effort to unite collides with several issues, namely the issue of group interests, regional interests, religious interests, and others. Therefore, from the very beginning in the idea of uniting the marines it must have a certain character to achieve its objectives. That character is a revolutionary character. ${ }^{10}$

In the main guideline for the implementation of the Marhaenis declaration, Soekarno stressed that Marhaenism is not just a political theory, but a theory of struggle. As Marxism is not just a theory, it is not just an economic theory, not just a political theory, but rather a theory. Marxists are the theory of the struggle to hit capitalism, to build a socialist society, as well as Marhaenism. The Marhaenism principle is the struggle against colonialism which ruled Indonesia through the mass-action of the Proletariat and peasants to fight capitalism and feudalism. Therefore, it is explicitly emphasized that Marhaenism is Marxism which is applied to the conditions and conditions of Indonesia.

In order to abort the imperialist system, the unity of the Marhaens is needed to hold mass action. The actions have always been the conduit when the old community stepped into the new society. The Marhaen must be mobilized in a conscious, radical mass movement. That is, in the movement of the masses who know well the path and purpose. Only a conscious and radical mass-action can be used to abort the form of imperialism and capitalism. To make the mass-action conscious and radical there is a need for a vanguard party that educates and leads the people on the journey towards victory.

Thus Marhaenism intends to focus on the masses and the masses only. All other groups are considered to hinder the independence movement and must be avoided altogether. Soekarno believed that in Marhaenism he had found a formula that included "practically all Indonesian people". Because, for example, "small traders" are included, the door is also open to others, because Soekarno considered himself not to be the spokesperson for only one group, but as he said at the time, "as the representative of the entire Indonesian people".

\footnotetext{
${ }^{10}$ What is meant by revolutionary is opposing capitalism. Said Bung Karno: "Well, here, enter into the people's movement that all must be revolutionary, meaning that all must oppose imperialism because who opposes imperialism, labor, marriage, employees, religious people, socialization, not formal democracy, who opposes imperialism is revolutionary. This is one group of unity than all the small people of Indonesia that I explained. "See Slamet Mulyana, National Awareness from Colonialism to Independence (Yogyakarta: LkiS, 2008), p. 187.
} 


\section{Discussion}

Until the end of 1930, the usual phrase for "little people" was "chromo". However, since the beginning of the PKI propaganda the term has often been used to refer to the proletariat. This forced Soekarno to look for a new term. One of Soekarno's biggest efforts in opposing elitism and raising the dignity of the small people in the process of the struggle for independence is of course the inception of the idea of marhaenism. Starting from his private meeting with Marhaen farmers. Soekarno felt called to give greater attention to the poor in Indonesia. He also felt the need to give a role to them in the struggle against capitalistic colonialism. These Marhaens, like the proletariat in the ideas of Karl Marx, are expected to be a major component in the revolution against colonialism and in creating a new, more just society. In its subsequent development, as said by Soekarno himself, Marhaenism will develop and become Indonesian Socialism in practice.

The Indonesian movement must be a movement that seeks energy only within Kang Kromo and Kang Marhaen, because Indonesia almost always has the Kromo and the Marhaen only. It was in the hands of the Kromo and the Marhaens that the location of the fate of Indonesia in particular, in the organization of the Kromo and the Marhaens, was primarily to be sought. ${ }^{11}$

In connection with efforts to overcome elitism, it was emphasized that Marhaenism rejected every act of bourgeoisie ${ }^{12}$ which, according to Soekarno, was the source of the existing imbalances in society. Soekarno argued that people should not have a low view of the people.

The concept of Marhaen as understood by Soekarno is similar but at the same time different from the concept of the proletariat of Marx. Like the proletariat, the Marhaens are poor, are in the lower ranks of society, and millions in number. But unlike the proletariat of Marx, the Marhaens did not work for others and they had their own means of production, such as hoes and cultivated land. According to Soekarno the understanding of the Marhaen was broader than the proletariat because the Marhaens included not only the workers, but also the peasants and every poor Indonesian. Whatever the similarities and differences, what needs to be understood for Soekarno is the effort to drive away every form of capitalism and imperialism.

Not long after Soekarno entered the Indonesian Party, Soekarno published an article, "Political Democracy and Economic-Democracy". He warned the Marhaens not to imitate the democracy practiced abroad, that such a form of democracy would not guarantee the welfare of the Marhaens, because he only gave political rights, while in the economic field the mass would continue to be in short supply. According to him, to reach a society without oppressed classes in Indonesia, it was not enough for Marhaens who would fight for it to become bourgeois revolutionaries with independence as their final goal. They must be social revolutionaries and must not stop before the happiness for everyone, for the entire Indonesian community. To the struggle, Soekarno gave a name that he had just created, namely Socionationalism or Socio-democracy. ${ }^{13}$

\footnotetext{
${ }^{11}$ Soekarno, Indonesia Menggugat (Jakarta: Fraksi PDI-Perjuangan DPR-RI, 2010), p. 125.

12 The bourgeoisie is the owner of the productive resources used by the proletariat to work. Bourgeois benefits mainly from interest, and loans, although it may receive other benefits in the form of salary or managerial duties and coordination of activities.

13 The ideas behind the Marhaenism principles: Sosionationalism and Sociodemocracy were analyzed to find out the Marxist content of Sukarno's Marhaenism. "Marhaenis is every person of the Indonesian nation who runs Marhaenism. That way, Marhaenis is every Indonesian who is willing to work together to build a just social
} 
Socio-nationalism aims to improve conditions in society so that there are no oppressed people, no wretched people, and no poor people. Socio-nationalism aims to seek political success and economic success, national success and sustenance.

Socio-democracy is born rather than Socio-nationalism aimed at seeking political and economic security, national security, and not only serving the interests of something small but to the interests of society. Socio-nationalism is humanitarian nationalism, generous nationalism, internationalism, nationalism which trembles to defend if you see it still there are colonized nations. Political democracy and economic democracy are parallel to marhaenism. If marhaenism is developed it will give birth: Socio-nationalism becomes humanitarian nationalism, Socio-democracy becomes a democracy of political sovereignty and social justice.

In 1933, Sukarno wrote in the People's Mind about Marhaen and Proletariat, namely a description of the decision of the Partindo conference (the Indonesian Party) concerning the new ideology in Mataram (Yogyakarta) which was expressed in the basic form of Marhaen and Marhaenism. In this article Soekarno tried to link Marhaenism with Marxism.

1. The first basic principle suggests that Marhaenism means social-nationalism and sociodemocracy.

2. The second basic principle states that Marhaen includes the proletariat, the peasantry, and other destitute people.

3. The third and fourth basic basis, Marhaen is wider than the proletariat, because it covers all kinds of destitute people.

4. The fifth basic foundation in the struggle (Partindo) believes that the proletariat takes a big part. Soekarno deliberately peeled off the basis of this fifth point. Although Marhaen shows differences with the proletariat. It is recognized that the role of the proletariat is very important, and it is mentioned as a modern aspect of Marhaenism because it is the proletariat who lives more in modern anti-colonialist and anti-imperialist ideologies. The modern ideology in question is none other than Marxism or Communism. ${ }^{14}$

The movement of Marxism in Indonesia in Sukarno's thought was to deny his character to a nationalist movement, and to deny the movement based on Islam. These three levels of thought dominate almost all of their thoughts and ideologies. ${ }^{15}$ This is due to the closeness with H.O.S. Tjokroaminoto is a figure of the Islamic islamic Surabaya. The spirit of anti-colonialism that gave birth to the spirit of nationalism and fondness for theory, Marxism.

"... here is made a very sharp difference of understanding between Marhaen and the proletariat, ... that Marhaen is not the proletariat (the workers) only. But the priests and the destitute peasants and other Indonesian destitute ... in the joint struggle of the proletariat and the people other destitute. It is the proletra who take a big part ".

The Marhenism developed by Soekarno as an alternative to the concept of the Marxist ploretariat. Soekarno, among others, wrote: Marhaenism is the principle that requires the composition of society and the structure of the state which in all cases saves Marhaen. Because everyone has the freedom to accept and reject and has the right to make their own choices.

order. Thus, not only is the idea of class struggle avoided, but also individuals are given the freedom to cooperate in the struggle of the poor and oppressed for a better future, regardless of their social and economic position and this applies even to the rich.

${ }^{14}$ Alfian, Pemikiran dan Perubahan Politik Indonesia (Jakarta: Gramedia, 2000), p. 123-124

${ }^{15}$ Soekarno, revolusi, p. 254. 


\section{Conclusion}

Marhaenism is a thought which born of rejection of a system that oppresses and afflicts the people. In this case Marhaenism has the nature of anti-oppression, anti-capitalism, colonialism / imperialism and feudalism and every other form of oppression.

To free themselves from the system that created misery for the people of Indonesia was by the way of the independence revolution. After independence was achieved, the course of the revolution was directed at the development of a just and prosperous society without an oppressive system. To achieve independence and a just and prosperous society, a revolutionary method of struggle must be developed. So from that Soekarno formulated Marhaenism as the theory of the struggle to achieve these ideals.

\section{References}

Alfian. Pemikiran dan Perubahan Politik Indonesia. Jakarta: Gramedia, 2000

Dham, Bernhard. Soekarno dan Perjuangan Kemerdekaan. Jakarta: LP3ES, 1987.

Feith, Herbert, et.al. The Indonesian Political Thingking, 1945-1965.

Kaelan, et.al. Pendidikan Kewarganegaraan. Yogyakarta: Paradigma, 2007.

Giebels, Lambert. Soekarno: Biografi 1901-1950. Jakarta: Grasindo, 2001.

Hartisekar,et.al. Mewaspadai Kuda Troya Komunisme di Era Reformasi. Jakarta: Pustaka Sarana Kajian, 2001.

Mulyana, Slame. Kesadaran Nasional dari Kolonialisme sampai Kemerdekaan. Yogyakarta: LkiS, 2008.

Soekarno. Indonesia Menggugat. Jakarta: Fraksi PDI-Perjuangan DPR-RI, 2010. 